\title{
USULAN PERBAIKAN KESELAMATAN KERJA MENGGUNAKAN METODE JOB SAFETY ANALYSIS (JSA) DAN FAILURE MODE AND EFFECT ANALYSIS (FMEA)
}

\author{
Ariel Levi \\ Program Studi Teknik Industri \\ Universitas Ma Chung Malang 65651 \\ 411110003@ student.machung.ac.id
}

\begin{abstract}
Abstrak
PT Prima Utama Mitra Anda adalah perusahaan yang bergerak di bidang industri pembuatan box karoseri. Proses produksinya banyak menggunakan alat atau mesin yang dapat menyebabkan kecelakaan kerja. Data perusahaan menunjukkan terdapat 73 kasus kecelakaan kerja pada tahun 2013 dan 107 kasus kecelakaan kerja pada tahun 2014. Dengan demikian, perlu dilakukan tindakan perbaikan guna menghindari terjadinya kerugian. Dalam penelitian ini digunakan metode Job Safety Analysis (JSA) dengan pendekatan metode Failure Mode and Effect Analysis (FMEA). Berdasarkan tahapan JSA, terdapat 86 jenis kecelakaan kerja dan diperoleh 5 pekerjaan kritis untuk dianalisis menggunakan metode FMEA. Setelah dilakukan perhitungan RPN, didapatkan 3 pekerjaan dengan tingkat kecelakaan paling tinggi, yaitu pekerjaan menggunakan mesin saw blade, pekerjaan menggunakan mesin las dan pekerjaan menggunakan mesin bor. Selanjutnya, pekerjaan tersebut diberi rekomendasi perbaikan berupa penyusunan Instruksi Kerja (IK). IK berisi langkah dasar pekerjaan, potensi bahaya, serta tata cara kerja yang benar. Selain menyusun IK, tingkat disiplin kerja juga perlu diperhatikan untuk membuktikan penyebab pasti kecelakaan kerja. Tingkat disiplin kerja dipengaruhi oleh beberapa faktor, yaitu tujuan dan kemampuan, teladan pimpinan, balas jasa, keadilan, pengawasan melekat, sanksi hukuman, ketegasan, dan hubungan kemanusiaan. Selain faktor-faktor tersebut, tingkat disiplin kerja dapat dibentuk melalui 2 cara, yaitu dengan disiplin preventif dan disiplin korektif.
\end{abstract}

Kata Kunci : Keselamatan dan Kesehatan Kerja (K3), Job Safety Analysis (JSA), Failure Mode And Effect Analysis (FMEA), Instruksi Kerja (IK), Disiplin kerja.

\section{PENDAHULUAN}

Keselamatan dan kesehatan kerja (K3) adalah hal yang tidak terpisahkan dalam sistem tenaga kerja yang berhubungan langsung dengan sumber daya manusia. K3 tidak saja penting dalam hal jaminan dan kesejahteraan sosial para pekerja, namun bisa berdampak positif terhadap keberhasilan produktivitas suatu perusahaan. Dengan adanya program K3, perusahaan bisa menghilangkan kasus kecelakaan yang mengakibatkan kerugian materi maupun kerugian jiwa. Kecelakaan kerja bisa diakibatkan oleh kurangnya pengetahuan dari tenaga kerja, keterampilan yang tidak memadai dalam pelaksanaan pekerjaanya, terutama ketika dihadapkan denga teknologi atau alat baru yang tidak sesuai dengan ukuran anthopometri tenaga kerja Indonesia (Suma'mur, 2009).

PT Prima Utama Mitra Anda (PUMA) merupakan salah satu perusahaan yang bergerak di bidang pembuatan karoseri untuk kendaraan pick up dan light truck. Perusahaan menjalankan proses produksinya berdasarkan tipe paket yang sudah disediakan. PT PUMA sebenarnya sudah menerapkan Sistem Manajemen Keselamatan dan Kesehatan Kerja (SM3K) yang baik. Namun, dalam proses produksi masih saja terjadi beberapa kasus kecelakaan kerja yang berulang. Kecelakaan kerja disebabkan oleh kurangnya perhatian para pekerja terhadap pentingnya keselamatan kerja bagi dirinya sendiri. Hal tersebut diperparah dengan belum adanya pengawasan dan sanksi yang tegas dari pihak manajemen perusahaan bagi pekerja yang melanggar peraturan mengenai keselamatan kerja.

Menurut data perusahaan, terdapat 73 dan 107 kasus kecelakaan kerja pada tahun 2013 dan 2014. Dengan melihat adanya potensi bahaya serta penanganan kecelakaan kerja yang belum berjalan dengan baik, perusahaan ini memerlukan Job Safety Analysis (JSA). JSA digunakan sebagai upaya untuk mengidentifikasi bahaya-bahaya yang terdapat di lingkungan kerja, beserta cara pengendalian atau penanggulangan guna mencegah kecelakaan dan penyakit akibat kerja yang mungkin timbul dari suatu pekerjaan. 
Sedangkan penggunaan pendekatanFailure Mode and Effect Analysis(FMEA) didasarkan pada alasan bahwa metode ini merupakan suatu teknik yang dapat digunakan untuk melakukan analisis penyebab potensial timbulnya suatu gangguan, probabilitas kemunculan, dan bagaimana cara pendeteksian dari gangguan tersebut (Febri, 2011).

\section{LANDASAN TEORI}

\section{A. Keselamatan dan Kesehatan Kerja (K3)}

K3 secara umum dapat diartikan sebagai upayaperlindungan yang ditujukanuntuktenaga kerjadan orang laindi tempat kerja agar selalu dalam keadaan selamat dan sehat, serta agar setiap proses produksi dilangsungkan secara aman dan efisien. Sedangkan secara keilmuan, K3 diartikan sebagai ilmu pengetahuan dan penerapannya guna mencegah kemungkinan terjadinya kecelakaan atau penyakit yang disebabkan oleh pekerjaan dan lingkungan kerja (Mahuri, 2010).

Tujuan dari K3 adalah untuk mewujudkan lingkungan kerja yang aman, sehat nan sejahtera, sehingga tercipta tenaga kerja yang sehat fisik maupun sosial, bebas kecelakaan, dan meningkatnya produktivitas dan efisiensi perusahaan. Usaha-usaha pelaksanaan K3 meliputi perlindungan terhadap tenaga kerjam perlindungan terhadap bahan dan peralatan produksi agar selalu terjamin keamanannya, serta perlindungan terhadap orang lain yang berada di lingkungan kerja agar tetap sehat dan selamat (Mahuri, 2010).

\section{B. Job Safety Analysis (JSA)}

JSA adalah suatu metode analisis untuk menilai resiko serta mengidentifikasi tindakan-tindakan kontrol yang diperlukan untuk menghilangkan atau mengurangi resiko yang ada (Rijanto, 2010). JSA merupakan salah satu langkah utama dalam analisis bahaya dan kecelakaan dalam upaya menciptakan keselamatan di lingkungan kerja. Apabila bahaya sudah bisa dikenali, maka dapat dilakukan tindakan pengendalian yang berupa perubahan fisik atau perbaikan prosedur kerja yang dapat mereduksi bahaya kerja. Tujuan dari metode JSA adalah untuk mengidentifikasi potensi bahaya di setiap aktivitas pekerjaan, sehingga tenaga kerja diharapkan mampu mengenali bahaya tersebut sebelum terjadi kecelakaan atau penyakit akibat kerja. Selain itu, metode JSA juga memiliki manfaat sebagai program jangka panjang untuk menanamkan kepedulian tenaga kerja terhadap kondisi lingkungan kerja guna menciptakan kondisi lingkungan kerja yang aman (Fauzi, 2009).

Di dalam pelaksanaan metode JSA, terdapat empat langkah dasar yang harus dilakukan, yaitu (Fauzi, 2009):

1. Menentukan pekerjaan yang akan dianalisis.

Langkah pertama dari pembuatan JSA adalah menentukan pekerjaan yang dianggap kritis dengan cara mengklasifikasi tugas yang mempunyai dampak paling besar. Dalam menentukan pekerjaan tersebut termasuk kritis atau tidak didasarkan pada frekuensi kecelakaan, kecelakaan yang menyebabkan luka, pekerjaan dengan potensi kerugian yang tinggi, serta pekerjaan baru yang dapat menyebabkan kecelakaan.

2. Menguraikan pekerjaan menjadi langkah-langkah dasar.

Dari pekerjaan yang dianggap kritis, dapat dibagi menjadi tahapan kerja yang pada akhirnya dapat digunakan menjadi suatu prosedur kerja. Tahapan kerja dapat diartikan bagian atau rangkaian dari keseluruhan pekerjaan. Untuk mengetahui tahapan kerja diperlukan observasi lapangan guna mengamati secara langsung bagaimana suatu pekerjaan dilakukan. Setelah melakukan observasi, dilihat kembali dan didiskusikan kepada kepala pimpinan yang bersangkutan untuk keperluan evaluasi dan mendapatkan persetujuan tentang apa yang dilakukan dalam pembuatan JSA. 
3. Mengidentifikasi bahaya pada masing-masing pekerjaan.

Identifikasi potensi bahaya merupakan alat manajemen untuk mengendalikan kerugian dan bersifat proaktif dalam upaya pengendalian bahaya di lingkungan kerja. Identifikasi bahaya dimaksudkan untuk mencegahterjadinya insiden dengan melakukan upaya-upaya seperti melakukan pengamatan secara dekat, mengetahui nhal-hal yang berhubungan dengan pekerjaan yang diamati, melakukan pengamatan dilakukan secara berulang, serta melakukan dialog dengan operator yang dinilai berpengalaman dalam pekerjaan yang diamati.

4. Mengendalikan bahaya

Langkah terakhir dalam metode JSA adalah mengembangkan prosedur kerja aman yang dapat dianjurkan untuk mencegah terjadinya suatu kecelakaan. Solusi yang dapat dikembangkan antara lain mencari cara lain untuk melakukan pekerjaan yang dianggap kritis, mengubah kondisi fisik yang dapat menimbulkan kecelakaan, menghilangkan bahaya dengan mengganti prosedur kerja yang sudah ada, rutin mengadakan tindakan perbaikan atau service, serta meninjau kembali rancangan pekerjaan yang sudah ada.

\section{Failure Mode and Effect Analysis (FMEA)}

FMEA merupakan suatu metode yang bertujuan untuk mengevaluasi desain sistem dengan mempertimbangkan bermacam-macam mode kegagalan dari sistem yang terdiri dari komponen-komponen dan menganalisis pengaruh-pengaruhnya terhadap keandalan sistem tersebut (Siswanto, 2010).Dengan penelusuran pengaruh kegagalan komponen sesuai dengan level sistem, item-item khusus yang kritis dapat dinilai dan tindakantindakan perbaikan diperlukan untuk memperbaiki desain dan mengeliminasi probabilitas dari mode-mode kegagalan yang kritis.

Dalam FMEA, dilakukan perhitungan Risk Priority Number (RPN) untuk menentukan tingkat kegagalan tertinggi. RPN merupakan hubungan antara tiga buah variabel yaitu(Siswanto, 2010):

1. Severity (Keparahan)

Severity adalah penilaian seberapa buruk atau serius dari pengaruh bentuk kegagalan yang ada dengan nilai ratingnya adalah 1 sampai 10 .

Tabel 1. Rating Severity(Cayman Bussiness System: FMEA, 2002)

\begin{tabular}{|c|l|}
\hline Rating & \multicolumn{1}{|c|}{ Criteria of Severity Effect } \\
\hline 10 & Kejadian fatal seperti kematian \\
9 & Trauma setelah kejadian \\
8 & Kerusakan tulang belakang \\
7 & Penderita hipertemia kehilangan kesadaran \\
6 & Patah tulang berat, iritasi berat, operasi dan amputasi \\
5 & Patah tulang ringan \\
4 & Luka robek, luka bakar, iritasi ringan dan hipertermia \\
3 & Pegal, terkilir dan tergores \\
2 & Alergi dan luka memar \\
1 & Iritasi ringan \\
\hline
\end{tabular}

2. Occurence (Frekuensi Kejadian)

Occurencemerupakan frekuensi dari penyebab kegagalan secara spesifik dari suatu proyek tersebut dan menghasilkan bentuk kegagalan dengan rating 1 sampai 10. Untuk menyesuaikan pada permasalahan yang ada, maka tabel occurence menggunakan interpolasi sederhana yaitu dengan menggunakan jumlah kejadian kecelakaan paling banyak terjadi dan nilai ranking tertinggi. Cara perhitungan interpolasi sederhana adalah: 


$$
\text { Rangking } X=\frac{y-y 1}{y 2-y 1}=\frac{x-x 1}{x 2-x 1}
$$

Keterangan:

$$
\begin{array}{ll}
\mathrm{y} & =\text { skor tertinggi } \\
\mathrm{y}_{1} & =\text { skor terendah } \\
\mathrm{y}_{2} & =\text { skor } \mathrm{x} \\
\mathrm{x} & =\text { nilai tertinggi } \\
\mathrm{x}_{1} & =\text { nilai terendah } \\
\mathrm{x}_{2} & =\text { nilai } \mathrm{x}
\end{array}
$$

Tabel 2. Rating Occurance (Cayman Bussiness System: FMEA, 2002)

\begin{tabular}{|l|c|l|c|}
\hline Probabilitas Kegagalan & $\begin{array}{c}\text { Probabilitas Terjadinya } \\
\text { Kegagalan per Tahun }\end{array}$ & Possible Failure Rate & Rank \\
\hline Hampir selalu & $>500$ & $\geq 1$ dalam 2 & 10 \\
Sangat tinggi & $366-500$ & 1 dalam 3 & 9 \\
Tinggi & $300-365$ & 1 dalam 8 & 8 \\
Agak tinggi & $250-300$ & 1 dalam 20 & 7 \\
Medium & $150-249$ & 1 dalam 80 & 6 \\
Rendah & $50-149$ & 1 dalam 400 & 5 \\
Sedikit & $10-49$ & 1 dalam 2000 & 4 \\
Sangat sedikit & $5-9$ & 1 dalam 15000 & 3 \\
Sangat sedikit sekali & $1-4$ & 1 dalam 150000 & 2 \\
Hampir tidak pernah & $<1$ & 1 dalam 1500000 & 1 \\
\hline
\end{tabular}

\section{Detection (Deteksi Kegagalan)}

Deteksi diberikan pada sistem pengendalian yang digunakan saat ini yang memiliki kemampuan untuk mendeteksi penyebab atau mode kegagalan dengan rating 1 sampai 10.

Tabel 3. Rating Detection (Cayman Bussiness System: FMEA, 2002)

\begin{tabular}{|l|l|c|}
\hline \multicolumn{1}{|c|}{ Detection } & \multicolumn{1}{|c|}{ Probability of Detection } & Rank \\
\hline Tidak terdeteksi & Tidak ada alat pengontrol yang mampu mendeteksi & 10 \\
Sangat sedikit & Alat pengontrol saat ini sangat sulit mendeteksi bentuk dan & 9 \\
kemungkinan & penyebab kegagalan & \\
Sedikit & Alat pengontrol saat ini sulit mendeteksi bentuk dari penyebab & 8 \\
kemungkinan & kegagalan & \\
Sangat rendah & Kemampuan alat kontrol untuk mendeteksi bentuk dan penyebab & 7 \\
Rendah & sangat rendah & 6 \\
Cukup & Kemampuan alat kontrol untuk mendeteksi dan penyebab rendah & 6 \\
Cukup tinggi & Kemampuan alat kontrol untuk mendeteksi dan penyebab sedang & 5 \\
Tinggi & sampai tinggi & 4 \\
Sangat tinggi & $\begin{array}{l}\text { Kemampuan alat kontrol untuk mendeteksi dan penyebab tinggi } \\
\text { tinggi }\end{array}$ & 3 \\
Hampir pasti & Kemampuan alat kontrol untuk mendeteksi dan penyebab hampir & 2 \\
\hline
\end{tabular}

\section{Instruksi Kerja(IK)}

IK merupakan dokumen kerja yang digunakan sebagai panduan dalam melaksanakan suatu operasi tertentu yang dijelaskan secara baku, rinci, urut dan sistematis, dan hanya melibatkan satu fungsi atau departemen saja. Di dalam dokumen IK biasanya merinci langkah urutan sebuah aktivitas yang bersifat spesifik dan harus jelas, akurat sertatidak boleh mengandung penjelasan yang meragukan (Wishnu, 2008). 
Dapat menyusun IK yang benar merupakan salah satu keuntungan dari menerapkan metode JSA, yang meliputi mempelajari dan membuat laporan setiap langkah pekerjaan, identifikasi potensi bahaya maupun bahaya pekerjaan yang sudah ada dan menentukan jalan terbaik untuk mengurangi atau mengeliminasi bahaya tersebut. Berikut adalah contoh IK berdasarkan metode JSA:

Tabel 4. Instruksi Kerja Berdasarkan Metode Job Safety Analysis (JSA) (Arini, 2014)

\begin{tabular}{|c|c|c|c|}
\hline \multirow{3}{*}{ Logo } & Jenis Pekerjaan: & Tanggal: & $\begin{array}{l}\square \text { Baru } \\
\square \text { Revisi }\end{array}$ \\
\hline & Supervisor: & \multicolumn{2}{|c|}{ Analisa oleh: } \\
\hline & Departemen: & \multicolumn{2}{|c|}{ Revisi oleh: } \\
\hline \multicolumn{2}{|c|}{ Rekomendasi Perlindungan Diri Menggunakan Peralatan seperti: } & \multirow{2}{*}{\multicolumn{2}{|c|}{$\begin{array}{l}\text { Disetujui oleh: } \\
\quad \text { Tata Cara Kerja } \\
\text { Berdasarkan dua kolom } \\
\text { sebelumnya sebagai acuan, } \\
\text { berikan tata cara kerja yang } \\
\text { benar untuk dilakukan sebaga } \\
\text { langkah meminimalisir } \\
\text { kecelakaan dan cedera yang } \\
\text { parah. }\end{array}$}} \\
\hline $\begin{array}{l}\text { Uraikan secara singkat langkah- } \\
\text { langkah dasar pekerjaan. }\end{array}$ & $\begin{array}{l}\quad \text { Potensi Bahaya } \\
\text { Identifikasi potensi bahaya } \\
\text { yang berpeluang muncul dari } \\
\text { masing-masing langkah } \\
\text { pekerjaan. }\end{array}$ & & \\
\hline
\end{tabular}

\section{E. Disiplin Kerja}

Disiplin kerja adalah suatu sikap menghormati, menghargai, patuh dan taat terhadap peraturan-peraturan yang berlaku baik yang tertulis maupun yang tidak tertulis, serta sanggup menjalankan dan tidak mengelak untuk menerima sanksisanksinya apabila tenaga kerja yang bersangkutan melanggar tugas dan wewenang yang diberikan kepadanya (Dessler, 2008). Dalam kaitannya dengan pekerjaan, disiplin kerja dapat dilihat dari sikap dan tingkah laku yang memiliki kehendak untuk menaati segala peraturan yang didasarkan atas kesadaran diri dan tanpa adanya paksaan dari pihak manapun.

Terdapat beberapa faktor yang mempengaruhi timbulnya disiplin kerja, yaitu (Hasibuan, 2005):

1. Tujuan dan kemampuan, yaitu pekerjaan yang dibebankan harus sesuai dengan kemampuan tenaga kerja itu sendiri.

2. Teladan pimpinan, yang sangat berperan dalam menentukan sikap disiplin kerja tenaga kerja karena pimpinan selalu dijadikan panutan oleh para bawahannya.

3. Balas jasa, yang harus sesuai dengan hak para tenaga kerja.

4. Keadilan, yaitu penyamarataan perlakuan pimpinan terhadap bawahan.

5. Pengawasan melekat (waskat), yaitu memberikan pengawasan langsung kepada bawahan sehingga para tenaga kerja akan selalu mendapat perhatian.

6. Sanksi hukuman, yaitu pemberian sanksi terhadap para tenaga kerja yang terbukti melanggar peraturan yang berlaku.

7. Ketegasan, yaitu sikap yang dimiliki oleh pimpinan untuk menghukum para tenaga kerja yang melakukan kesalahan.

8. Hubungan kemanusaiam, yaitu hubungan baik yang bersifat vertikal maupun horizontal dalam lingkup kerja.

Selain beberapa faktor diatas, secara garis besar disiplin kerja dapat dibentuk melalui dua cara, yaitu (Handoko, 2001):

1. Disiplin Preventif, yaitu tindakan yang diambil untuk mendorong para pekerja mengikuti atau mematuhi norma dan aturan yang berlaku sehingga tidak terjadi penyelewengan. Tujuannya adalah untuk mendorong disiplin diri pekerja dan menghilangkan rasa paksaan dari atasan.

2. Disiplin Korektif, yaitu tindakan yang diambil untuk menangani pelanggaran terhadap aturan yang bisa berupa hukuman atau tindakan pendisiplinan. 


\section{METODOLOGI PENELITIAN}

\section{A. Pengumpulan Data}

Dalam penelitian ini, tahap pengumpulan data dibagi menjadi dua, yaitu data primer dan data sekunder. Data primer diperoleh melalui observasi dan wawancara kepada pihak-pihak yang berkepentingan di area produksi PT PUMA, seperti manajer direktur, kepala departemen atau supervisor. Data primer yang didapat akan digunakan dalam proses pembuatan tabel failure, mode and effect, pembobotan nilai severity, occurance, dan detection. Sedangkan data sekunder didapatkan dari dokumen atau arsip yang berhubungan dengan proses produuksi dan berupa data historis perusahaan selama beberapa periode tertentu. Data sekunder yang dibutuhkan adalah profil perusahaan, struktur organisasi perusahaan, proses produksi, serta data historis kecelakaan selama dua tahun terakhir.

\section{B. Tahap Penelitian}

Dalam penelitian ini, tahap penelitian dilakukan untuk mengumpulkan informasi yang bersifat umum. Tahap penelitian dibagi menjadi beberapa tahap.

1. Tahap Pendahuluan

Pada tahap pendahuluan terdapat lima langkah, yaitu:

- Survey Pendahuluan Langkah awal yang dilakukan adalah mengamati situasi, kondisi, dan gambaran mengenai kebijakan perusahaan serta melakukan wawancara dengan pihak perusahaan khususnya pada masalah K3.

- Identifikasi Masalah Identifikasi bertujuan untuk mencari penyebab timbulnya masalah yang ada pada area produksi PT PUMA.

- Studi Literatur Studi literatur dilakukan untuk mendapatkan informasi yang relevan dengan permasalahan yang akan diteliti.

- Perumusan Masalah Perumusan masalah dilakukan sesuai dengan identifikasi masalah yang terjadi di PT PUMA.

- Tujuan Penelitian Tujuan penelitian harus dirumuskan sesuai dengan perumusan masalah, agar langkah penelitian dapat dijalankan sesuai dengan yang sudah direncanakan.

2. Tahap Pengolahan Data

Pada tahap pengolahan data, terdapat tiga tahapan yang dilakukan. Berikut adalah penjelasan dari tahapan-tahapan yang harus dilakukan, meliputi (Fauzi, 2009):

- Menentukan jenis pekerjaan

Langkah pertama adalah mengidentifikasi pekerjaan yang dianggap kritis, megacu pada faktor-faktor seperti frekuensi kecelakaan, tingkat kecelakaan, potensi kecelakaan, dan pekerjaan baru.

- Melakukan prosedur di dalam metode JSA

a. Menguraikan pekerjaan menjadi langkah dasar

Setelah menentukan jenis pekerjaan, langkah selanjutnya adalah melakukan pengamatan proses kerja bersama supervisor, kepala departemen dan operator. Observasi poengamatan dilakukan untuk memberi gambaran mengenai tahapan pekerjaan yang dilakukan tenaga kerja dan mengetahui kondisi lingkungan serta bahaya yang mungkin timbul.

b. Mengidentifikasi bahaya pada masing-masing pekerjaan

Proses selanjutnya adalah identifikasi potensi bahaya untuk menentukan akibat yang ditimbulkan dari masing-masing pekerjaan. Berdasarkan proses identifikasi tersebut, maka pada tahap ini pengembangan JSA menggunakan 
metode FMEA sebagai dasar untuk menentukan prioritas pekerjaan. Berikut adalah tahapan FMEA (Siswanto, 2010):

- Identifikasi produk/jasa

- Identifikasi failure mode potensial

- Identifikasi failure effect dan penyebabnya dari masalah potensial tersebut

- Tentukan nilai severity

- Tentukan nilai occurance

- Tentukan nilai detection

- Hitung nilai RPN untuk menentukan prioritas tindakan yang tepat.

c. Mengembangkan solusi

Langkah terakhir adalah dengan mengembangkan prosedur kerja yang sesuai untuk mencegah terjadinya kasus kecelakaan kerja.

3. Analisis dan Pembahasan

Data penelitian yang telah diolah kemudian dianalisis, dan dijadikan pedoman dalam melakukan perbaikan. Untuk perbaikan bisa berupa penyusunan Instruksi Kerja (IK) yang baru sehingga pekerja lebih memperhatikan aspek keselamatan kerja. Selain itu, faktor disiplin kerja juga perlu diperhatikan. Hal ini dilakukan untuk membuktikan apakah kasus kecelakaan kerja yang terjadi hanya disebabkan oleh belum adanya perbaikan yang sesuai untuk masalah yang ada pada PT PUMA.

\section{HASIL DAN PEMBAHASAN}

\section{A. Pelaksanaan Job Safety Analysis (JSA)}

Dalam pelaksanaan JSA, terdapat empat langkah dasar yang dilakukan. Berikut adalah langkah-langkah pelaksanaan JSA:

\section{Menentukan Pekerjaan yang akan Dianalisis}

Terdapat 86 jenis kecelakaan kerja yang dapat teridentifikasi pada area produksi PT PUMA, dengan total 73 kecelakaan kerja pada tahun 2013 dan 107 kecelakaan kerja pada tahun 2014. Berdasarkan dasar teori JSA, didapatkan lima pekerjaan kritis yang akan dianalisis, mengacu pada frekuensi pekerjaan dengan potensi kerugian berupa kecelakaan kerja pada pekerja. Lima pekerjaan tersebut adalah pekerjaan menggunakan mesin saw blade, pekerjaan menggunakan mesin las, pekerjaan menggunakan mesin paku rivet dan tang rivet, pekerjaan menggunakan mesin bor, serta pekerjaan menggunakan Electric Sealent Gun.

\section{Menguraikan Pekerjaan Menjadi Langkah-langkah Dasar}

Dari setiap pekerjaan yang sudah ditentukan, dapat dibagi menjadi beberapa tahapan beruntun yang dapat digunakan menjadi suatu prosedur kerja. Berikut adalah uraian langkah-langkah dasar dari masing-masing pekerjaan yang sudah ditentukan:

a) Pekerjaan Menggunakan Mesin Saw Blade

Mesin saw blade adalah mesin yang berfungsi untuk memotong benda kerja dengan kecepatan sekitar 1800-2200 rpm. Kegunaan mesin saw blade yaitu memotong profil aluminium, guna mendapatkan hasil yang sudah ditentukan. Prosedur kerja penggunaan mesin saw blade adalah sebagai berikut:

- Tahap Persiapan

- Mempersiapkan alat pelindung diri (APD) yang lengkap.

- Mempersiapkan peralatan dan alat bantu mesin saw blade seperti tang jepit.

- Penyetelan peralatan mesin saw blade

- Menghubungkan kabel power ke stop kontak.

- Melepas pengaman pisau mesin saw blade.

- Proses memotong benda kerja

- Letakkan benda kerja pada mesin saw blade.

- Pasangkan dua tang jepit ke benda kerja. 
- Tekan pelatuk pistol mesin agar pisau berputar sesuai dengan kecepatan yang dibutuhkan.

- Arahkan tuas mesin saw blade ke benda kerja yang akan dipotong.

- Akhir pekerjaan

- Melepas tang japit yang dipasang pada benda kerja.

- Pasang kembali pengaman pisau mesin saw blade.

- Melepas kabel power penghubung dari stop kontak.

- Membersihakn kotoran yang ada pada mesin dan lingkungan kerja.

b) Pekerjaan Menggunakan Mesin Las

Mesin las digunakan untuk menggabungkan dua profil aluminium agar menjadi bentuk yang sudah ditentukan. Prosedur kerja penggunaan mesin las adalah sebagai berikut:

- Tahap Persiapan

- Mempersiapkan alat pelindung diri (APD) yang lengkap.

- Mempersiapkan peralatan dan alat bantu mesin las.

- Penyetelan peralatan mesin las

- Menghubungkan kabel las dan kabel kontrol.

- Menekan tombol on dan penyetelan penggunaan arus las Direct Current Reverse Polarity (DCRP).

- Penyetelan wire feeder, welding gun, dan gas $\mathrm{CO}_{2}$.

- Proses pengelasan

- Tekan pelatuk pistol las

- Tempelkan ujung elektroda ke benda kerja.

- Akhir pekerjaan

- Tutup katup gas pelindung.

- Setel kecepatan kawat pada posisi nol.

- Tutup katup gas pada regulator.

- Matikan mesin penggerak kawat.

- Matikan mesin las

- Rapikan alat yang sudah selesai digunakan.

c) Pekerjaan Menggunakan Paku Rivet dan Tang Rivet

Paku rivet digunakan sebagai alat penyambung profil aluminium agar tersusun secara rapi dan kuat. Dalam penggunaannya, paku rivet bisa terpasang hanya dengan bantuan tang rivet dengan ukuran yang sama. Prosedur kerja penggunaan paku dan tang rivet adalah sebagai berikut:

- Tahap Persiapan

- Mempersiapkan alat pelindung diri (APD) yang lengkap.

- Mempersiapkan peralatan berupa paku rivet dan tang rivet.

- Penggunaan peralatan paku dan tang rivet

- Mengambil beberapa paku rivet yang akan digunakan.

- Memasukkan paku rivet ke dalam tang rivet.

- Proses meyatukan profil aluminium

- Letakkan profil aluminium pada lantai yang datar.

- Tandai dan beri jarak $10 \mathrm{~cm}$ pada profil aluminium yang akan diberi paku rivet.

- Arahkan dan tekan tang rivet secara berulang hingga ujung paku rivet menancap dengan sempurna.

- Akhir pekerjaan

- Membersihkan kotoran yang ada pada tang maupun pada lingkungan kerja.

- Meyimpan kembali alat yang sudah digunakan.

d) Pekerjaan Menggunakan Mesin Bor

Mesin bor digunakan untuk melubangi profil aluminium sebagai ruang untuk 
pemasangan baut. Prosedur kerja penggunaan mesin bor adalah sebagai berikut:

- Tahap Persiapan

- Mempersiapkan alat pelindung diri (APD) yang lengkap.

- Mempersiapkan peralatan dan alat bantu mesin bor dan mata bor.

- Penyetelan peralatan mesin bor.

- Memasang mata bor dengan menggunakanchuck key.

- Menghubungkan kabel power ke stop kontak.

- Proses mengebor

- Tekan tombol trigger untuk menghidupkan mesin.

- Arahkan mata bor ke benda kerja.

- Melepas tombol trigger untuk mematikan mesin.

- Akhir pekerjaan

- Melepas kabel power dari stop kontak.

- Melepas mata bor dari mesin bor.

- Membersihkan kotoran pada mesin bor maupun pada lingkungan kerja.

- Menyimpan alat yang sudah digunakan.

e) Pekerjaan Menggunakan Electric Sealent Gun

Electric Sealent Gun digunakan untuk menyemprotkan cairan sealent ke profil aluminium yang sudah disatukan. Tujuannya adalah sebagai pengisi, penambal dan perekat celah pada sambungan profil aluminium agar terlihat rapat, erat dan anti bocor. Prosedur kerja penggunaan Electric Sealent Gun:

- Tahap Persiapan

- Mempersiapkan alat pelindung diri (APD) yang lengkap.

- Mempersiapkan peralatan berupa tabung cairan sealent.

- Penyetelan Electric Sealent Gun

- Menghubungkan kabel power ke stop kontak.

- Memasukkan tabung cairan sealent ke dalam Electric Sealent Gun.

- Proses menyemprotkan cairan sealent

- Membersihkan profil aluminium yang sudah disatukan.

- Membersihkan celah-celah kosong dari debu atau serpihan kasar.

- Tekan pelatuk pistol Electric Sealent Gun.

- Arahkan ujung Electric Sealent Gun ke dalam celah-celah profil aluminium hingga terisi penuh dan tertutup rapat.

- Akhir pekerjaan

- Melepaskan tabung selaent yang terpasang pada Electric Sealent Gun.

- Melepas kabel power pada stop kontak.

- Membersihkan kotoran yang ada pada lingkungan kerja.

- Rapikan alat yang sudah selesai digunakan.

\section{Identifikasi Bahaya pada Masing- masing Pekerjaan}

a) Pekerjaan Menggunakan Mesin Saw Blade

- Tahap Persiapan

Potensi bahaya yang muncul adalah jari atau tangan bisa terjepit tang yang sangat kuat. Hal ini disebabkan karena pekerja biasanya kurang berhati-hati dalam penggunaan alat bantu ini.

- Penyetelan peralatan mesin las.

Potensi bahaya yang timbul adalah bahaya keselamatan electrical berupa terkena aliran listrik. Selain itu, potensi bahaya yang timbul adalah bahaya keselamatan yaitu bahaya mechanical berupa tergores pada saat melakukan pelepasan pengaman.

- Proses memotong benda kerja

Terdapat beberapa potensi bahaya keselamatan berupa bahaya mechanical. 
Bahaya yang pertama adalah mata terkena serpihan kasar akibat benda kerja yang mengalami gesekan dengan pisau saw blade. Bahaya yang kedua adalah bagian tubuh seperti bibir, dada, leher, kepala dan lengan terkena pecahan dari benda kerja yang dipotong oleh pisau saw blade. Kecelakaan kerja tersebut bisa terjadi akibat para pekerja tidak menggunakan APD dengan lengkap.

- Akhir pekerjaan

Terdapat potensi bahaya keselamatan yaitu bahaya mechanical seperti tangan tergores pada saat memasang kembali pengaman pisau mesin saw blade. Hal ini dapat terjadi karena permukaan pisau yang tajam. Selain itu potensi bahaya yang timbul adalah bahaya keselamatan physical seperti menghirup debu dan serpihan serbuk yang dihasilkan oleh benda kerja.

b) Pekerjaan Menggunakan Mesin Las

- Tahap Persiapan

Potensi bahaya yang terjadi adalah bahaya kesehatan pada bagian tubuh, sebagai contoh adalah tangan terkilir akibat membawa mesin las MIG yang cukup berat. Selanjutnya adalah mempersiapkan peralatan dan alat bantu mesin las MIG. Potensi bahaya yang muncul adalah terkilir pada saat membawa tabung gas $\mathrm{CO}_{2}$ dan menggunakan peralatan yang rusak atau belum diperiksa.

- Penyetelan peralatan mesin las.

Tahap penyetelan mesin las memiliki potensi bahaya yaitu terlilit dan terjatuh akibat kabel yang tidak rapi, tergores elektroda, terkena aliran listrik dan tertimpa tabung gas $\mathrm{CO}_{2}$.

- Proses pengelasan

Terdapat beberapa potensi bahaya keselamatan berupa bahaya mechanical. Bahaya yang pertama adalah mata merah akibat radiasi sinar las, luka bakar pada bagian tubuh, menghirup debu dan asap, serta kaki tertimopa material. Kecelakaan kerja tersebut bisa terjadi akibat para pekerja tidak menggunakan APD dengan lengkap.

- Akhir pekerjaan

Pada tahap akhir pekerjaan, potensi bahaya yang timbul adalah terlilit kabel las, karena jumlah kabel las tidak sedikit dan panjang, dan mengakibatkan kaki terlilit sehingga pekerja bisa terjatuh.

c) Pekerjaan Menggunakan Paku Rivet dan Tang Rivet

- Tahap Persiapan

Potensi bahaya yang muncul adalah jari atau tangan bisa tergores ujung paku yang tajam. Hal ini disebabkan karena pekerja biasanya kurang berhati-hati dalam mengambil paku rivet di dalam wadah yang sudah disediakan.

- Penggunaan peralatan paku dan tang rivet

Potensi bahaya yang timbul adalah bahaya keselamatan mechanical berupa tangan tergores akibat ujung paku yang tajam. Hal tersebut bisa terjadi karena pekerja kurang memperhatikan posisi paku rivet.

- Proses menyatukan profil aluminium

Terdapat beberapa potensi bahaya keselamatan berupa bahaya mechanical. Bahaya yang pertama adalah bagian tubuh seperti mata, dada dan leher terkena lemparan dari kepala lepas paku rivet yang ditekan oleh tang rivet. Bahaya yang kedua adalah kaki menginjak paku rivet, akibat paku rivet tidak terpasang dengan benar pada tang rivet. Kecelakaan kerja tersebut bisa terjadi akibat para pekerja tidak menggunakan APD dengan lengkap.

- Akhir pekerjaan

Pada tahap akhir pekerjaan, terdapat potensi bahaya keselamatan yaitu 
bahaya mechanical seperti tangan tergores pada saat membersihkan sisa-sisa paku rivet yang tidak terpakai, serta kaki terinjak kepala lepas paku rivet akibat berserakan di sekitar lingkungan kerja. Hal ini dapat terjadi karena ujung paku yang tajam.

d) Pekerjaan Menggunakan Mesin Bor

- Tahap Persiapan

Potensi bahaya yang terjadi adalah bahaya kesehatan yaitu bahaya ergonomi berupa cidera pada beberapa bagian tubuh seperti pada pergelangan tangan, telinga dan mata. Selanjutnya mempersiapkan peralatan dan alat bantu seperti mata bor dan chuck key. Potensi bahaya yang timbul adalah bahaya keselamatan yaitu bahaya mechanical berupa tergores saat memegang mata bor karena permukaan mata bor yang tajam sehingga dapat berpotensi tergores jika dipegang dengan tangan. Selain itu potensi bahaya bisa berasal dari menggunakan peralatan yang rusak atau belum di inspeksi kelayakannya seperti menggunakan mata bor yang kurang tajam dan mesin bor yang rusak.

- Penyetelan peralatan mesin bor

Potensi bahaya yang timbul adalah bahaya keselamatan yaitu bahaya mechanical berupa tergores pada saat melakukan pemasangan mata bor. Selanjutnya menghubungkan kabel power ke stop kontak. Potensi bahaya yang timbul adalah bahaya keselamatan electrical berupa terkena aliran listrik. Aliran listrik dapat terjadi ketika terdapat luka pada kabel mesin.

- Proses pengeboran

Terdapat beberapa potensi bahaya keselamatan mechanical yaitu gangguan pendengaran, mata terkena serpihan aluminium, tangan terkena bor, serta menghirup debu dan serpihan aluminium.

- Akhir pekerjaan

Terdapat potensi bahaya keselamatan yaitu bahayamechanical seperti tangan tergores pada saat melakukan pelepasan mata bor. Hal ini dapat terjadi karena permukaan mata bor yang tajam. Selain itu potensi bahaya yang timbul adalah bahaya keselamatan physical seperti menghirup debu dan serpihan serbuk aluminium.

e) Pekerjaan Menggunakan Electric Sealent Gun

- Tahap Persiapan

Potensi bahaya yang muncul adalah terlilit dan terjatuh akibat kabel yang sangat panjang dan tidak rapi.

- Penyetelan Electric Sealent Gun

Potensi bahaya yang timbul adalah bahaya keselamatan electrical berupa terkena aliran listrik akibat adanya luka atau terkelupasnya kabel mesin.

- Proses menyemprotkan cairan sealent

Terdapat beberapa potensi bahaya keselamatan berupa bahaya mechanical. Bahaya yang pertama adalah bagian tubuh seperti mata, leher, tangan dan kaki terkena cairan sealent yang dikeluarkan oleh mesin Electric Sealent Gun. Bahaya yang kedua adalah kaki terlilit kabel dan dapat mengakibatkan tubuh terjatuh akibat kabel yang terlalu panjang dan tidak dirapikan pada saat penggunaan.

- Akhir pekerjaan

Pada tahap akhir pekerjaan, terdapat potensi bahaya keselamatan yaitu bahaya mechanical seperti tangan terkena radiasi panas dari mesin Electric Sealent Gun akibat penggunaan dalam jangka waktu yang lama. 
Untuk melakukan identifikasi bahaya lanjutan yang efektif, diperlukan metode Failure Mode and Effect Analysis (FMEA) yang bertujuan untuk mengevaluasi desain sistem dengan mempertimbangkan bermacam-macam mode kegagalan dari sistem tersebut yang terdiri dari beberapa komponen.Identifikasi bahaya dengan menggunakan metode FMEA dilakukan dengan cara menganalisis pembobotan dari nilai severity (tingkat keparahan), occurance (frekuensi kecelakaan) dan detection (deteksi yang dilakukan), serta penentuan RPN untuk mengetahui pekerjaan mana yang akan menjadi prioritas untuk diambil langkah lebih lanjut.

a. Perhitungan Nilai Severity

Severity adalah suatu perkiraan subyektif atau estimasi bagaimana dampak yang disebabkan oleh suatu kegagalan. Penetapan nilai severity dari suatu jenis kecelakaan kerja diperoleh dari informasi lisan dengan pihak manajemen perusahaan. Kriteria verbal dan sistem peringkat untuk severity menggunakan skala 1-10. Skala severity ditentukan dari seberapa parah dampak yang ditimbulkan pada effect failure.

Contohnya adalah pada kasus terjatuh dari ketinggian yang mengakibatkan pekerja harus mengalami patah tulang pada bagian tangan. Sehingga penilaian severity berdasarkan tabel 1. masuk pada kriteria 6 yaitu patah tulang berat, iritasi berat, operasi dan amputasi.

b. Perhitungan Nilai Occurance

Occurance menyatakan seberapa sering kegagalan tersebut terjadi. Occurance menggunakan bentuk penilaian dengan skala 1 (tidak pernah) sampai 10 (hampir sering). Namun, untuk menyesuaikan pada permasalahan yang ada di perusahaan maka tabel occurance menggunakan interpolasi sederhana yaitu dengan jumlah kejadian kecelakaan paling banyak adalah 50 kali. Nilai 50 didapatkan dari jumlah kecelakaan yang paling sering terjadi pada masingmasing tahun, yaitu mata iritasi akibat serpihan saw blade sebesar 21 pada tahun 2013 dan 29 pada tahun 2014. Cara perhitungan interpolasi sederhana yang digunakan adalah:

Rangking $\mathrm{X}=\frac{\text { skor tertinggi-skor terendah }}{\text { skor } x-\text { skor terendah }}=\frac{\text { nilai tertinggi-nilai terendah }}{\text { nilai } x \text {-nilai terendah }}$

Misalkan pada probabilitas kegagalan yang memiliki kriteria pada rangking 2, berikut adalah contoh perhitungannya:

$$
\begin{aligned}
\text { Rangking } 2 & =\frac{\text { skor terting } \text { i-skor terendah }}{\text { skor } x \text {-skor terendah }}=\frac{\text { nilai terting } \text { i-nilai terendah }}{\text { nilai } x \text {-nilai terendah }} \\
= & \frac{10-1}{2-1}=\frac{50-0}{x-0} \\
X & =5,56=6
\end{aligned}
$$

Oleh karena itu, kriteria verbal dan sistem peringkat untuk occurance adalah sebagai berikut: 
Tabel 5. Rating Occurance(Cayman Bussiness System: FMEA, 2002)

\begin{tabular}{|c|c|c|c|}
\hline Rangking & Probabilitas Kegagalan & Kriteria & $\begin{array}{l}\text { Kejadian } \\
\text { ( } 2 \text { tahun) }\end{array}$ \\
\hline 10 & Hampir selalu & Kecelakaan selalu tinggi & $44-50$ \\
\hline 9 & Sangat tinggi & Kecelakaan terjadi sangat tinggi & $40-44$ \\
\hline 8 & Tinggi & Kecelakaan terjadi tinggi & 34-39 \\
\hline 7 & Agak tinggi & Kecelakaan terjadi agak tinggi & $29-33$ \\
\hline 6 & Sedang & $\begin{array}{l}\text { Kecelakaan terjadi pada tingkat } \\
\text { sedang }\end{array}$ & $23-28$ \\
\hline 5 & Rendah & $\begin{array}{l}\text { Kecelakaan terjadi pada tingkat } \\
\text { rendah }\end{array}$ & $18-22$ \\
\hline 4 & Sedikit & Kecelakaan sedikit terjadi & $12-17$ \\
\hline 3 & Sangat sedikit & Kecelakaan sangat sedikit terjadi & $7-11$ \\
\hline 2 & Sangat sedikit sekali & $\begin{array}{l}\text { Kecelakaan sangat sedikit sekali } \\
\text { terjadi }\end{array}$ & $1-6$ \\
\hline 1 & Tidak pernah & Kecelakaan tidak pernah terjadi & 0 \\
\hline
\end{tabular}

Skala occurance ditentukan dari seberapa banyak jumlah yang ditimbulkan pada failure. Contohnya pada kasus kaki tertimpa tabung $\mathrm{CO}_{2}$ yang berjumlah satu kali dalam dua tahun. Sehingga penilaian occurance berdasarkan Tabel 2 adalah pada rangking 2, dimana terdapat kriteria kejadian 1-6. Pada kejadian tersebut probabilitas kegagalan menunjukkan kecelakaan sangat sedikit sekali dengan kriteria verbal yaitu kecelakaan sangat sedikit sekali terjadi.

c. Perhitungan Nilai Detection

Detection merupakan gambaran tentang bagaimana efektifitas dan metode pendeteksian atau pencegahan. Perangkingan detection menggunakan bentuk penilaian dengan skala 1 (hampir pasti) sampai dengan 10 (tidak terdeteksi). Pemberian nilai detection pada berbagai kasus kecelakan diperoleh melalui informasi lisan pihak manajemententang penyebab terjadinya kecelakaan atau kegagalan (failure mode) dan pendeteksian yang sudah dilakukan oleh pihak perusahaan untuk menangani failure mode tersebut.

Contohnya adalah pada kasus kecelakaan kaki menginjak paku rivet sehingga mengakibatkan pekerja harus mengalami luka robek pada bagian kaki. Penyebab dari kecelakaan tersebut adalah pekerja tidak menggunakan sepatu kerja pada saat berada di lingkungan produksi. Pendeteksian yang sudah dilakukan pada kecelakaan tersebut adalah pengontrolan dari pihak manajemen perusahaan yang dibantu oleh kepala departemen. Dalam hal ini kepala departemen sangat berperan penting dalam hal pengawasan kepada masingmasing pekerja yang dibawahinya. Akan tetapi, hal tersebut masih dirasa sangat kurang karena pihak manajemen tidak optimal dan seakan acuh akan tindakan dari para pekerjanya. Selain itu, perusahaan juga masih belum menerapkan peraturan wajib penggunaan alat pelindung diri (APD). Sehingga penilaian detection adalah sebesar 6, dimana terdapat kriteria verbal yaitu kemampuan alat kontrol, dalam hal ini adalah manajer direktur dan kepala departemen, untuk mendeteksi bentuk dan penyebab kecelakaan rendah.

d. Perhitungan Risk Priority Number RPN)

Setelah didapatkan hasil nilai severity $(\mathrm{S})$, occurance $(\mathrm{O})$ dan detection $(\mathrm{D})$ dari masing-masing kegagalan, maka langkah selanjutnya adalah menentukan niali RPN. Nilai RPN didapat dari perkalian antara severity, occurance dan detection.

$$
R P N=S \times O \times D
$$

Contoh perhitungan RPN pada kasus kecelakaan kerja tangan terkena bor adalah nilai severity sebesar 4 karena pekerja mengalami luka robek pada 
tangan, nilai occurance sebesar 2 karena terjadi tiga kali dalam dua tahun, serta nilai detectionsebesar 6 karena kontrol dari kepala departemen terhadap karyawan yang dibawahi masih rendah.

$$
\begin{aligned}
R P N & =S \times O \times D \\
\mathrm{RPN} & =4 \times 2 \times 6 \\
& =48
\end{aligned}
$$

e. Prioritas Berdasarkan RPN

Pada tahap ini dilakukan penghitungan nilai kritis berdasarkan Risk Priority Number (RPN). Langkah ini merupakan tahap akhir prosedur analisis dengan metode FMEA, dimana melalui perangkingan akan diperoleh urutan prioritas penanganan kecelakaan kerja yang terjadi di perusahaan. Perhitungan nilai kritis RPN mengikuti rumus sebagai berikut:

$$
\text { Nilai Kritis } R P N=\frac{\text { Total } R P N}{\text { Jumlah Resiko }}
$$

Oleh karena itu, nilai kritis RPN adalah sebagai berikut:

$$
\begin{aligned}
\text { Nilai Kritis RPN } & =\frac{\text { Total RPN }}{\text { Jumlah Resiko }} \\
& =\frac{3003}{2950} \\
& =60,06
\end{aligned}
$$

Dari perhitungan diatas, maka didapatkan nilai kritis sebesar 60,06. Artinya, jenis kecelakaan yang memiliki nilai RPN diatas nilai kritis RPN akan dianalisis lebih lanjut. Oleh karena itu, prioritas perbaikan diberikan kepada kegagalan yang memiliki nilai RPN diatas nilai kritis.

Berdasarkan perhitungan nilai kritis RPN terdapat enam pekerjaan dengan prioritas utama, yaitu pekerjaan menggunakan mesin saw blade dengan nilai RPN 600 dan 360, pekerjaan menggunakan mesin las dengan nilai RPN sebesar 300 dan 180, serta pekerjaan menggunakan mesin bor dengan nilai RPN sebesar 216 dan 144. Dari hasil diatas, didapatkan tiga pekerjaan dengan tingkat kecelakaan paling tinggi. Selanjutnya, pekerjaan menggunakan mesin-mesin tersebut akan diberi rekomendasi berupa penyusunan Instruksi Kerja (IK) yang baru.IK berisi langkah-langkah dasar pekerjaan, potensi bahaya yang terjadi, serta tata cara kerja yang benar.

\section{Mengendalikan Bahaya}

a) Pekerjaan Menggunakan Mesin Saw Blade

- Tergores permukaan pisau mesin saw blade. Rekomendasi perbaikan yaitu dengan menggunakan APD berupa safety gloves dengan bahan kain rajut yang dapat mencegah terjadinya goresan pada kulit akibat benda yang kasar dan tajam.

- Jari terjepit tang jepit. Rekomendasi perbaikan yaitu pastikan peralatan yang digunakan masih dalam kondisi normal dan layak pakai, serta pastikan tidak ada komponen yang terlepas pada saat tang akan digunakan.

- Terkena aliran listrik. Rekomendasi perbaikan yaitu memastikan kondisi kabel power atau kabel mesin dalam kondisi baik atau kering. Penggunaan safety shoes juga sangat dianjurkan sebagai pencegahan terhadap aliran listrik.

- Mata terkena serpihan kasar aluminium. Rekomendasi perbaikan yaitu dengan menggunakan safety googles yang dirancang untuk memberi perlindungan pada sekitar mata. 
- Bagian tubuh seperti bibir, dada, leher, kepala dan lengan terkena pecahan dari benda kerja yang dipotong oleh pisau saw blade. Rekomendasi perbaikan yaitu dengan penggunaan APD berupa safety helmet, face shield dan baju kerja/wearpack.

- Menghirup serpihan kasar aluminium. Rekomendasi perbaikan yaitu menggunakan masker yang dapat mencegah masuknya debu, serpihan serbuk aluminium dan partikel-partikel halus lainnya ke dalam pernafasan.

- Kaki terkena material yang tajam. Rekomendasi perbaikan yaitu dengan menggunakan safety shoes.

b) Pekerjaan Meggunakan Mesin Las

- Terkilir pada saat membawa mesin las MIG. Rekomendasi perbaikan adalah dengan menggunakan alat bantu berupa trolley pada saat pengangkatan alat mesin las MIG.

- Terkena kejutan listrik. Rekomendasi perbaikan adalah dengan memastikan bahwa kondisi kabel power atau kabel mesin las masih dalam keadaan baik dan tidak terkelupas. Selain itu, penggunaan safety shoes juga dianjurkan sebagai langkah antisipasi terhadap aliran listrik.

- Tergores kawat elektroda. Rekomendasi perbaikan adalah dengan menggunakan safety gloves jenis kain katun rajut yang dapat mencegah terjadinya goresan terhadap benda kasar dan tajam.

- Luka bakar pada bagian tubuh. Rekomendasi perbaikan adalah dengan menggunakan pakaian kerja untuk menghindari radiasi panas yang dihasilkan oleh mesin las MIG.

- Tertimpa material. Rekomendasi perbaikan yang diberikan yaitu gunakan alat bantu untuk menyanggah benda yang berada diatas dan gunakan safety helmet.

- Mata merah akibat iritasi. Rekomendasi perbaikan yang diberikan yaitu dengan menggunakan safety googles atau kedok las pada saat proses pengelasan berlangsung.

- Radiasi sinar las. Rekomendasi perbaikan yang diberikan yaitu dengan menggunakan apron.

- Menghirup asap pengelasan. Rekomendasi perbaikan yaitu menggunakan masker yang dapat mencegah masuknya debu, serpihan serbuk aluminium dan partikelpartikel halus lainnya ke dalam pernafasan.

c) Pekerjaan Menggunakan Mesin Bor

- Gangguan pendengaran. Rekomendasi perbaikan menggunakan ear plug untuk menutup telinga dan meminimalisir gangguan pendengaran yang bisa terjadi pada pekerja akibat tingkat kebisingian yang dihasilkan oleh mesin bor.

- Tergores mata bor pada saat penggunaan mesin bor maupun pada saat melakukan pelepasan mata bor. Rekomendasi perbaikan yaitu menggunakan APD berupa safety gloves dengan bahan kain rajut yang dapat mencegah terjadinya goresan pada kulit akibat benda yang kasar dan tajam.

- Terkena aliran listrik. Rekomendasi perbaikan yaitu memastikan kondisi kabel power atau kabel mesin dalam kondisi baik atau kering. Penggunaan safety shoes juga sangat dianjurkan sebagai pencegahan terhadap aliran listrik.

- Mata terkena serpihan aluminium. Rekomendasi perbaikan yaitu menggunakan safety googlesdan face shield yang dirancang untuk memberi perlindungan pada sekitar mata.

- Tangan terkena bor. Rekomendasi perbaikan yaitu menggunakan kedua tangan pada saat memegang mesin bor dan menggunakan jig/alat bantu untuk memegang objek. 
- Menghirup debu dan serpihan aluminium. Rekomendasi perbaikan yaitu menggunakan masker yang dapat mencegah masuknya debu, serpihan serbuk aluminium dan partikel-partikel halus lainnya ke dalam pernafasan.

- Tertimpa material aluminium. Rekomendasi perbaikan yaitu gunakan alat bantu untuk menyanggah benda yang berada diatas dan gunakan safety helmet.

\section{B. Disiplin Kerja pada PT. PUMA}

Dalam kasus ini, disiplin kerja yang diamati adalah disiplin kerja dari pegawai produksi PT. PUMA. Pengamatan dilakukan untuk membuktikan apakah kecelakaan kerja yang terjadi pada area produksi PT. PUMA hanya disebabkan oleh belum adanya Instruksi Kerja (IK) yang sesuai untuk pekerjaan yang memiliki nilai kritis.

Dari hasil pengamatan yang sudah dilakukan, dapat disimpulkan bahwa tingkat kecelakaan kerja yang terjadi pada area produksi PT. PUMA tidak hanya disebabkan oleh belum adanya IK yang sesuai dari pekerjaan-pekerjaan yang memiliki nilai kritis. Tingkat kecelakaan kerja juga bisa terjadi akibat kurangnya disiplin kerja pada pegawai yang disebabkan oleh kurangnya teladan dari pimpinan, serta belum adanya sanksi hukuman yang tegas bagi para pekerja yang melakukan pelanggaran seperti tidak menggunakan alat pelindung diri (APD) yang lengkap pada saat bekerja. Sikap dan tingkah laku pekerja merupakan sesuatu yang tidak muncul dengan sendirinya, namun perlu dibentuk. Oleh karena itu, pembentukan disiplin kerja dapat dilakukan melalui dua cara, yaitu:

1. Disiplin Preventif

Disiplin preventif bisa dilakukan dengan cara memberikan reward atau penghargaan bagi pekerja yang taat dan selalu mengikuti peraturan perusahaan dengan baik. Penghargaan bisa berupa bonus gaji atau pemberian berupa barang, sehingga pekerja bisa termotivasi untuk selalu taat dan disiplin dalam bekerja.

2. Disiplin Korektif

Disiplin korektif bisa dilakukan dengan cara menyusun sanksi hukuman yang tegas bagi pegawai yang melakukan pelanggaran. Sanksi hukuman yang dijatuhkan bisa berupa sanksi ringan sampai berat. Sebagai contoh, pelanggaran yang sering terjadi adalah pegawai tidak menggunakan alat pelindung diri (APD) dan dapat menyebabkan kecelakaan kerja. Sanksi hukuman yang diberikan adalah potong gaji dengan nominal yang telah disepakati oleh manajer direktur dan pegawai itu sendiri. Hal tesebut bisa memberikan efek jera pada pegawai yang melakukan pelanggaran, sehingga para pegawai yang lain tidak mengulangi pelanggaran yang sama.

\section{KESIMPULAN DAN SARAN}

\section{A. Kesimpulan}

Kesimpulan yang dapat diambil dari penelitian ini adalah:

1. Terdapat lima pekerjaan yang dianggap kritis dan dianalisis menggunakan metode Job Safety Analysis (JSA). Pekerjaan tersebut adalah pekerjaan dengan menggunakan mesin saw blade, pekerjaan menggunakan mesin las MIG, pekerjaan menggunakan paku rivet dan tang rivet, pekerjaan menggunakan mesin bor tangan, dan pekerjaan menggunakan mesin Electric Sealent Gun.

2. Setelah melakukan proses identifikasi bahaya menggunakan metode Failure Mode and Effect Analysis (FMEA), hasil perhitungan Risk Priority Number (RPN) diketahui bahwa tiga jenis kecelakaan kerja yang harus diprioritaskan karena melebihi nilai kritis RPN sebesar 60,06 dan harus ditangani lebih lanjut menggunakanyaitu pekerjaan menggunakan mesin saw blade dengan nilai RPN 600 
dan 360, pekerjaan menggunakan mesin las dengan nilai RPN sebesar 300 dan 180, serta pekerjaan menggunakan mesin bor dengan nilai RPN sebesar 216 dan 144.

3. Rekomendasi akhir yang diberikan sesuai dengan metode JSA adalah dengan menyusun Instruksi Kerja (IK) yang berisi penggunaan alat pelindung diri (APD) yang dibutuhkan, potensi bahaya apa saja yang dihadapi, serta tindakan apa yang diperlukan untuk mengantisipasi potensi bahaya yang bisa saja muncul. Selain dengan menyusun IK yang sesuai, disiplin kerja para pegawai juga harus diperhatikan. Disiplin kerja tersebut masih bisa dibentuk dengan cara melakukan tindakan disiplin preventif dan disiplin korektif guna mendukung tindakan JSA yang sudah dilakukan dan bisa meminimalisir tingkat kecelakaan kerja pada area produksi PT PUMA.

\section{B. SARAN}

Saran yang dapat diberikan untuk penelitian selanjutnya adalah penambahan metodeyang bertujuan sebagai tindakan pengawasan dan identifikasi bahaya dari dasar demi mendapatkan perbaikan yang konsisten. Selain itu, penelitian selanjutnya diharapkan dapat membantu perusahaan dalam pembuatan sanksi hukuman bagi para pegawai serta pembuatan sistem manajemen keselamatan dan kesehatan kerja (SMK3) yang sesuai.

\section{DAFTAR PUSTAKA}

[1] Arini, T.S., 2014,Mudah Menyusun SOP (Standard Operating Procedure), Penebar Plus ${ }^{+}$, Jakarta.

[2] Davis, K., 2004, Perilaku Dalam Organisasi: Edisi Ketujuh, Erlangga, Jakarta.

[3] Failure Mode and Effect Analysis. 2002. Cayman Business System. Page 81-83.

[4] Fauzi, S. A. 2009,Job safety Analysis Sebagai Langkah Awal dalam Upaya Pencegahan Terjadinya Kecelakaan Akibat Kerja di Area Attachment Fabrication PT. Sanggar Sarana Baja Jakarta Timur, Tugas Akhir, Teknik Industri, Universitas Negeri Surakarta, Surakarta.

[5] Handoko, T.H., 2001, Manajemen Personalia dan Sumber Daya Manusia, BPFE, Yogyakarta.

[6] Hasibuan, M.S., 2005, Manajemen Pengertian dan Masalah, Haji Mas Agung, Jakarta.

[7] Mahuri, 2010,Hubungan Pengetahuan Keselamatan Kerja Dengan Pelaksaan Pencegahan Kecelakaan Kerja. Bengkulu: SMKN 4 Bengkulu. http://www. mahurianasla.com/2010/11/hubungan-pengetahuan- keselaman-kerja.html.

(Diakses pada 21 Agustus 2015).

[8] Rijanto, B., 2010,Pedoman Praktis Keselamatan, Kesehatan Kerja dan Lingkungan $(K 3 L)$, Mitra Wacana Media, Indonesia.

[9] Siswanto, Y., 2010, Perancangan Preventive Maintenance Berdasarkan Metode Reliability Centered Maintenance Pada PT. Sinar Sosro, Tugas Akhir, Teknik Industri, Universitas Sumatera Utara, Medan.

[10] Suma'mur, P. K., 2009, Higiene Perusahaan dan Kesehatan Kerja, CV. Sagung Seto, Jakarta.

[11] Wishnu, A.P., 2008, Smart Business Series: Cara Mudah Menguasai Ilmu Logistik, Elex Media Komputindo, Jakarta. 